\title{
The late Holocene record of Lake Mareotis, Nile Delta, Egypt
}

\author{
Clément Flaux $^{1}$, Matthieu Giaime ${ }^{2, a}$, Valérie Pichot ${ }^{3}$, Nick Marriner $^{4}$, Mena el-Assal $^{5}$, Abel Guihou $^{6}$, \\ Pierre Deschamps $^{6}$, Christelle Claude $^{6}$, and Christophe Morhange ${ }^{6}$ \\ ${ }^{1}$ Mosaïques Archéologie, Cournonterral, 34660, France \\ ${ }^{2}$ Department of Geography, Durham University, Durham DH1 3LE, UK \\ ${ }^{3}$ CEAlex, CNRS, USR3134, Alexandria, Egypt \\ ${ }^{4}$ Chrono-Environnement, CNRS-UFC, UMR 6249, Besançon, 25000, France \\ ${ }^{5}$ Department of Geography, Faculty of Humanities, King Khalid University, Abha, 62529, Saudi Arabia \\ ${ }^{6}$ Aix Marseille Univ, CNRS, IRD, INRAE, Coll France, CEREGE, Aix-en-Provence, 13090, France \\ a present address: Institute of Environmental Science and Technology (ICTA-UAB), Universitat Autònoma de Barcelona, \\ Bellaterra, 08193 Catalonia, Spain
}

Correspondence: Clément Flaux (c.flaux@mosaiquesarcheologie.com)

Relevant dates: $\quad$ Received: 28 August 2020 - Revised: 8 February 2021 - Accepted: 17 February 2021 Published: 8 April 2021

How to cite:

Flaux, C., Giaime, M., Pichot, V., Marriner, N., el-Assal, M., Guihou, A., Deschamps, P., Claude, C., and Morhange, C.: The late Holocene record of Lake Mareotis, Nile Delta, Egypt, E\&G Quaternary Sci. J., 70, 93-104, https://doi.org/10.5194/egqsj-70-93-2021, 2021.

Abstract:

Lake Maryut (northwestern Nile Delta, Egypt) was a key feature of Alexandria's hinterland and economy during Greco-Roman times. Its shores accommodated major economic centers, and the lake acted as a gateway between the Nile valley and the Mediterranean. It is suggested that lake-level changes, connections with the Nile and the sea, and possible high-energy events considerably shaped the human occupation history of the Maryut. To reconstruct Lake Maryut hydrology in historical times, we used faunal remains, geochemistry (Sr isotopic signature of ostracods) and geoarcheological indicators of relative lake-level changes. The data show both a rise in Nile inputs to the basin during the first millennia BCE and CE and a lake-level rise of ca. $1.5 \mathrm{~m}$ during the Roman period. A high-energy deposit, inferred from reworked radiocarbon dates, may explain an enigmatic sedimentary hiatus previously attested to in Maryut's chronostratigraphy.

Kurzfassung: In griechisch-römischer Zeit spielte der Maryut-See (nordwestliches Nil-Delta, Ägypten) eine wirtschaftliche Schlüsselrolle im Hinterland von Alexandria. An seinen Ufern befanden sich wichtige Wirtschaftszentren und der See fungierte als Bindeglied zwischen dem Niltal und dem Mittelmeer. Es ist zu vermuten, dass Schwankungen des Seespiegels, Verbindungen zum Nil und zum Mittelmeer und mögliche Hochenergieereignisse die menschliche Besiedlungsgeschichte des Maryut-Sees beachtlich geprägt haben. Um die Hydrologie des Maryut-Sees in historischer Zeit zu rekonstruieren, untersucht diese Studie Faunenreste, geochemische (Sr-Isotopensignaturen von Ostrakoden) und geoarchäologische Indikatoren, die relative Schwankungen des Seespiegels anzeigen. Die Ergebnisse zeigen sowohl einen Anstieg der Nileinträge in den See während des ersten Jahrtausends v. Chr. und n. Chr. als auch einen Anstieg des Seespiegels um ca. 1,5 m während der Römerzeit. Ein Hochenergieereignis, ausgewiesen durch umgelagerte ${ }^{14} \mathrm{C}$ Alter, könnte die Ursache eines rätselhaften Hiatus in den Pro- 
filen sein, der zuvor in der Chronostratigraphie des Maryut-Sees nachgewiesen wurde. (Abstract was translated by Martin Seeliger.)

\section{Introduction}

Lake Mareotis, precursor of the modern Maryut lagoon located just south of Alexandria (Egypt), constituted a dense traffic waterway during antiquity (Empereur, 1998), straddling the northwestern Nile Delta. Extensive archeological surveys have shed new light on the intense occupation of its shores between the 4th century BCE and the 7th century CE (Blue and Khalil, 2010). An archeological synthesis at the scale of the western delta has demonstrated that paleowaterways and the overall hydraulic configuration shaped the geography of ancient settlements (Wilson, 2012). Our knowledge and representation of the ancient water network is primarily based upon historical statements, in particular Strabo (Strabo, XVII, 1, 7; translation Yoyotte et al., 1997), according to whom Lake Mareotis was connected to the Nile through several canals on its southern and eastern sides. Lake-level oscillations were then mediated by Nile floods. Nonetheless, this vision furnishes a static view of the lake, whose shores were occupied for a period of 1000 years or more, as recently underscored at Kom el-Nogous close to Taposiris Magna (Fig. 1), occupied during the New Kingdom (Redon et al., 2017). Following Stanley (2019) quoting Butzer (1976, p. 56), "it has become difficult to ignore the possibility that major segments of ancient Egyptian history may be unintelligible without recourse to an ecological perspective." We suggest that this statement resonates strongly with the human occupation history of Lake Mareotis, as originally perceived by De Cosson (1935).

Lake Mareotis is part of the coastal belt of the Nile Delta, spread over a structural boundary which separates Pleistocene coastal sandstone ridges to the west and northwest from the Holocene Nile Delta to the east and southeast (Fig. 1). This situation at the deltaic margin made it very sensitive to hydrological changes, modulated by Holocene relative sea-level changes (e.g., Goiran et al., 2018) and Nile flow modifications (e.g., Sun et al., 2019). We have previously exploited Lake Mareotis sedimentary archives in order to reconstruct its Holocene history (Flaux et al., 2011, 2012, 2013, 2017), aiming to elucidate the ancient geography and hydrology of the lake. The marine transgression of the area is dated to $7.5 \mathrm{kacal} \mathrm{BP}$. Nile inputs then became progressively predominant in Maryut's hydrology (7-5.5 ka cal BP) in the context of the African Humid Period (AHP). Between 5.5 and $2.8 \mathrm{kacal} \mathrm{BP}$, the end of the AHP is translated by a progressive hydrological shift from a Nile-dominated to a marine-dominated lagoon. A hiatus in Maryut's sedimentary record precludes investigating the lagoon system between 2.8 and $1.7 \mathrm{kacalBP}$. The final phase from 1.7 to
$0.2 \mathrm{ka}$ cal BP was characterized by dominant freshwater inputs except between 1.1 to $0.7 \mathrm{kacal} \mathrm{BP}$, when a Maryut relative lowstand and seawater intrusion are attested. New biosedimentological, geochemical, radiocarbon and geoarcheological data have helped to shed new light on the evolution of Lake Mareotis' water budget during historical times. In particular, this paper aims to better constrain hydrological conditions of the lake during the Greco-Roman period and probe the sedimentary hiatus previously described within the lake sequence (Goodfriend and Stanley, 1996; Flaux et al., 2012).

\section{Materials and methods}

This study is based on sedimentary sequences retrieved from archeological structures and Lake Maryut. All localities have been benchmarked relative to mean sea level (tide-gauge data from Alexandria taken in 1906) using a differential GPS.

Akadémia and Kôm de la Carrière are two Roman archeological sites lying on the southwestern waterfront of Lake Maryut (Fig. 1). At Akadémia, one sedimentary core was taken from a flooded kiln chamber (core AKA19; $30^{\circ} 59^{\prime} 16.74^{\prime \prime} \mathrm{N} 29^{\circ} 40^{\prime} 23.56^{\prime \prime} \mathrm{E}$ ). Another core (AKA12; $30^{\circ} 59^{\prime} 12.31^{\prime \prime} \mathrm{N} 29^{\circ} 40^{\prime} 07.68^{\prime \prime} \mathrm{E}$; WGS 84 coordinate system) was retrieved from the sedimentary filling of a water-wheel well (Egyptian sakieh). Cores were taken in 2015 using a percussion corer Cobra TT and relevant sediment samples were extracted for wet sieving and binocular observation of the sand fraction. The base of the kiln chamber is used as an upper limit of the water table and the base of the well as a lower one. The chronology of both structures, based on their archeological dating (Pichot and Flaux, 2015; Pichot, 2017), shows the evolution of the water-table elevation, related to the adjacent Lake Maryut base level.

At Kôm de la Carrière eight sedimentary cores were collected in 2015 from a ancient silted quarry (Fig. 2). Core AMR-3 $\left(31^{\circ} 01^{\prime} 07.15^{\prime \prime} \mathrm{N}, 29^{\circ} 44^{\prime} 07.27^{\prime \prime} \mathrm{E}\right.$; WGS84 coordinate system), drilled in the center of the basin, underwent sediment grain size and ostracod analyses at Durham University. We used wet sieving to quantify the sediment texture, including the coarse fraction $(>2 \mathrm{~mm})$, sand fraction $(50 \mu \mathrm{m}-2 \mathrm{~mm})$ and silty-clay fraction $(<50 \mu \mathrm{m})$. Ostracods were picked from the $>125 \mu \mathrm{m}$ fraction using a binocular microscope and identified to species level (Athersuch et al., 1989). The core chronology is based on three radiocarbon dates (Table 1), as well as ceramics studied at the Centre d'Etudes Alexandrines (CEAlex; CNRS, Alexandria).

The stratigraphy of Maryut lagoon's southeastern basin was investigated using the new sedimentary section M83, collected in 2014 from the section of a drain crossing the for- 


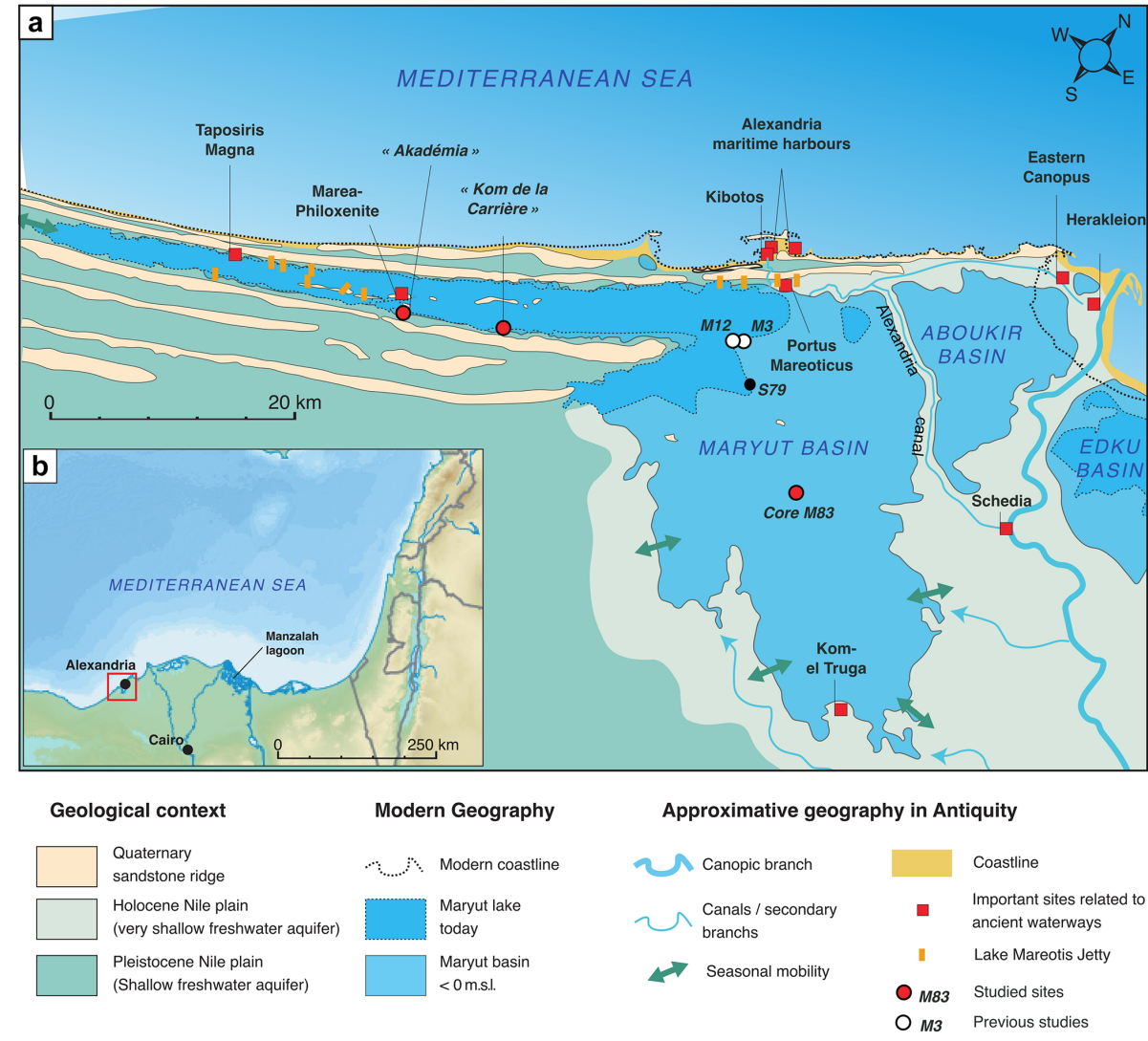

Figure 1. (a) Geomorphological map of Lake Mareotis at the northwestern edge of the Nile Delta. (b) Location of the study area along the southeastern Mediterranean Sea.

mer lagoon bottoms, now cultivated (Fig. $1 ; 31^{\circ} 2^{\prime} 39.24^{\prime \prime} \mathrm{N}$, $30^{\circ} 2^{\prime} 21.52^{\prime \prime} \mathrm{E}$; WGS84 coordinate system). A continuous set of 66 samples, each $2 \mathrm{~cm}$ thick, was taken from a $1.4 \mathrm{~m}$ thick sequence. Bio-sedimentary analyses were undertaken at CEREGE (CNRS, France). We used wet sieving to quantify the sediment texture (including the coarse fraction $(>2 \mathrm{~mm})$, sand fraction $(50 \mu \mathrm{m}-2 \mathrm{~mm})$ and silty-clay fraction $(<50 \mu \mathrm{m})$. Ostracods were picked from the $>125 \mu \mathrm{m}$ fraction using a binocular and identified to species level (Athersuch et al., 1989). Sorted mollusk shells were assigned to ecological assemblages according to modern faunal groups observed on the Nile coast (Bernasconi and Stanley, 1994). Magnetic susceptibility measurements were undertaken using a Bartington MS2 magnetic susceptibility meter and are reported as mass-specific magnetic susceptibility in SI units $\left(10^{-8} \mathrm{~m}^{3} \mathrm{~kg}^{-1}\right)$. Strontium isotopes were measured on ostracod valves for 29 samples (ca. 30 when available; Table 2). Reinhardt et al. (1998) analyzed $\mathrm{Sr}$ isotopic ratios on surface and subsurface shell samples taken from Manzala lagoon in the eastern Nile Delta and showed that this proxy could be used to reconstruct the recent desalinization of the lagoon, attributed to increasing Nile inflow from the modern irrigation system. Similar results were obtained from the modern northwestern Nile coast (Flaux, 2012, vol. III, p. 13-20) and applied to Maryut's Holocene sedimentary archives (Flaux et al., 2013). For the ${ }^{87} \mathrm{Sr} /{ }^{86} \mathrm{Sr}$ analyses of section M83, we selected the euryhaline ostracod Cyprideis torosa due to the species' wide tolerance to hydrological changes (Frenzel and Boomer, 2005). Clean shells were selected and washed with Milli-Q water and then dissolved in a $3 \mathrm{~N} \mathrm{HNO}_{3}$ solution. $\mathrm{Sr}$ separation and purification techniques used $\mathrm{Sr} \mathrm{Spec}$ resin following the procedure modified by Pin et al. (1994). Sr isotopic measurements were performed with a NEPTUNE+ Multicollector ICP-MS at CEREGE. A total of 13 replicate analyses of the NBS 987 standard yielded a ${ }^{87} \mathrm{Sr} /{ }^{86} \mathrm{Sr}$ ratio of $0.710264 \pm 0.000023(2 \sigma)$, providing a standard error of $\pm 32 \mathrm{ppm}$ (parts per million). The chronology of core M83 is based on seven radiocarbon dates (Table 1).

\section{Geoarcheological indicators}

\subsection{Sediment record from a silted quarry at Kôm de la Carrière}

The Kôm de la Carrière site is located on the southwestern shore of Lake Maryut (Fig. 1) at the foothill of a Pleistocene ridge mostly made of poorly consolidated aeolian oolitic carbonate sands (Gebel Maryut ridge; El Asmar and Wood, 
Table 1. Radiocarbon data from the Kôm de la Carrière site (core AMR-3) and section M83. The ${ }^{14} \mathrm{C}$ activity was calibrated using the software Calib 8.2 (http://calib.org, last access: February 2021) and the IntCal20 curve (Reimer et al., 2020). No reservoir age correction was applied to radiocarbon ages (see discussion in Flaux et al., 2012, p. 3497). Extracted collagen was used for the bone sample Poz-88215.

\begin{tabular}{lrrll}
\hline Laboratory code & Conventional ${ }^{14} \mathrm{C}$ age & Error & Material & $\begin{array}{l}\text { Calibrated BCE/CE } \\
(\text { IntCal20; } \sigma)\end{array}$ \\
\hline Poz-114734 & 111.84 pMC & 0.54 pMC & Plant remains & Recent \\
Poz-114735 & 1050 & 80 & Plant remains & $774-1198 \mathrm{CE}$ \\
Poz-114736 & 2205 & 30 & Organic sediment & $371-175 \mathrm{BCE}$ \\
Beta-406936 & 130 & 30 & Charcoal & $1673-1942 \mathrm{CE}$ \\
Poz-89003 & 2310 & 50 & Bittium reticulatum shell & $537-203 \mathrm{BCE}$ \\
Poz-89004 & 2465 & 30 & Bittium reticulatum shell & $760-418 \mathrm{BCE}$ \\
Poz-88215 & $>46.000$ & - & Burnt bone fragment & $>45700 \mathrm{BCE}$ \\
SacA 16171 & 2655 & 30 & Cerastoderma valve & $898-788 \mathrm{BCE}$ \\
Poz-88214 & 1195 & 30 & Organic residue & $706-950 \mathrm{CE}$ \\
Poz-89005 & 1845 & 30 & Bittium reticulatum shell & $122-308 \mathrm{CE}$ \\
\hline
\end{tabular}

Table 2. Sr isotope data from the ostracod Cyprideis torosa extracted in section M83.

\begin{tabular}{|c|c|c|c|c|}
\hline \multicolumn{2}{|c|}{$\begin{array}{l}\text { Sample depth below } \\
\text { the surface }(\mathrm{cm})\end{array}$} & \multicolumn{3}{|c|}{ Sr isotopic ratio } \\
\hline & & $\begin{array}{l}\text { Cyprideis torosa } \\
\text { number of valves }\end{array}$ & ${ }^{87} \mathrm{Sr} /{ }^{86} \mathrm{Sr}$ & StdErr (abs) \\
\hline 2 & 4 & 31 & 0.7088923 & $6.8995 \times 10^{-06}$ \\
\hline 6 & 8 & 32 & 0.7086547 & $7.1254 \times 10^{-06}$ \\
\hline 10 & 12 & 32 & 0.7086056 & $7.3353 \times 10^{-06}$ \\
\hline 16 & 18 & 30 & 0.7089906 & $6.8555 \times 10^{-06}$ \\
\hline 22 & 24 & 25 & 0.7088767 & $8.4143 \times 10^{-06}$ \\
\hline 32 & 34 & 32 & 0.7090380 & $7.2522 \times 10^{-06}$ \\
\hline 36 & 38 & 37 & 0.7090952 & $5.6228 \times 10^{-06}$ \\
\hline 40 & 42.5 & 29 & 0.7090651 & $7.8184 \times 10^{-06}$ \\
\hline 45 & 46 & 28 & 0.7084412 & $7.0303 \times 10^{-06}$ \\
\hline 50 & 52 & 32 & 0.7085629 & $6.9299 \times 10^{-06}$ \\
\hline 54 & 56 & 33 & 0.7083908 & $6.9392 \times 10^{-06}$ \\
\hline 58 & 60 & 46 & 0.7083415 & $6.1782 \times 10^{-06}$ \\
\hline 66 & 68 & 38 & 0.7084961 & $7.3548 \times 10^{-06}$ \\
\hline 68 & 70 & 29 & 0.7086069 & $7.2733 \times 10^{-06}$ \\
\hline 74 & 76 & 23 & 0.7085054 & $7.3531 \times 10^{-06}$ \\
\hline 78 & 80 & 26 & 0.7086150 & $6.7636 \times 10^{-06}$ \\
\hline 82 & 84 & 23 & 0.7087141 & $7.1005 \times 10^{-06}$ \\
\hline 86 & 88 & 16 & 0.7084723 & $6.7583 \times 10^{-06}$ \\
\hline 92 & 94 & 20 & 0.7086781 & $6.4997 \times 10^{-06}$ \\
\hline 98 & 100 & 23 & 0.7083944 & $8.8246 \times 10^{-06}$ \\
\hline 102 & 104 & 26 & 0.7086270 & $7.0049 \times 10^{-06}$ \\
\hline 108 & 110 & 26 & 0.7081114 & $7.7709 \times 10^{-06}$ \\
\hline 110 & 112 & 25 & 0.7087512 & 0.00002 \\
\hline 114 & 116 & 25 & 0.7087348 & $4.73 \times 10^{-06}$ \\
\hline 116 & 118 & 30 & 0.7089914 & $6.9982 \times 10^{-06}$ \\
\hline 118 & 120 & 38 & 0.7089995 & $4.94 \times 10^{-06}$ \\
\hline 122 & 123 & 34 & 0.7090287 & $1.83 \times 10^{-05}$ \\
\hline 126 & 128 & 17 & 0.7090530 & $4.57 \times 10^{-06}$ \\
\hline 130 & 135 & 57 & 0.7086334 & $4.68 \times 10^{-06}$ \\
\hline
\end{tabular}




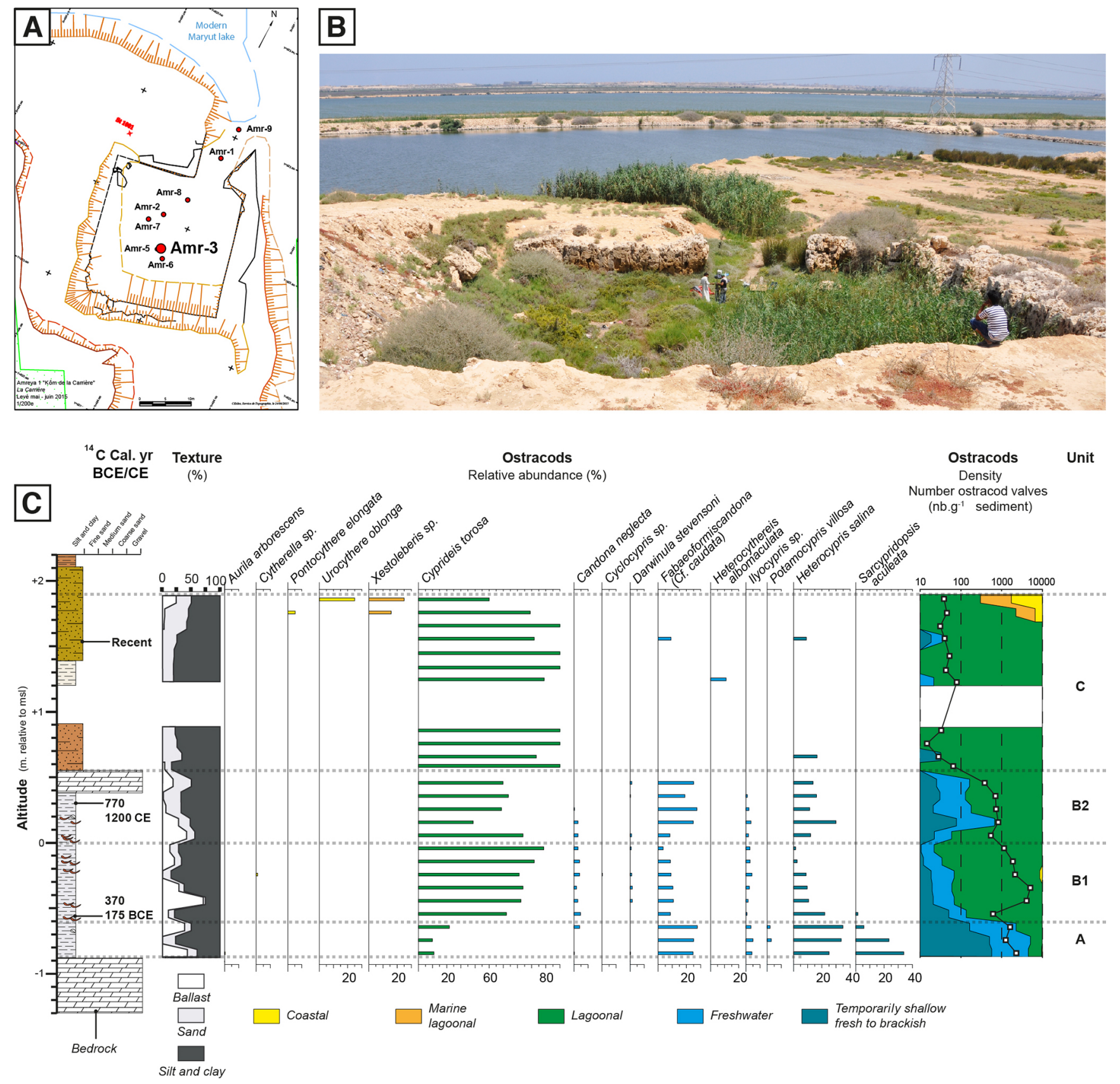

Figure 2. Kôm de la Carrière archeological site. Map (a) and photograph (b) of the silted quarry open toward Lake Maryut (C) CEAlex archive). The quarry was hypothetically used as a lake harbor. Eight cores were taken from the silted quarry to test this hypothesis. Stratigraphy and ostracod species and assemblages of core AMR-3 are given in (c).

2000). This bedrock has been carved in the form of a boxshaped quarry opening onto Lake Maryut (Fig. 2), which led El-Fakharani (1991) to suggest that this structure was later used as a protected harbor in ancient times. Core AMR-3 was taken from the silted quarry in order to test this hypothesis. Three main units were elucidated along the sedimentary sequence.
Unit A is composed of light gray silts and clays (56\%). The sand and gravel fractions respectively represent $17 \%$ and $27 \%$ of the sediment texture. The ostracods comprise an association of freshwater to brackish (86\%) and lagoonal (14\%) species. Heterocypris salina and Sarcypridopsis aculeata, indicative of temporary fresh to brackish water environments, constitute $52 \%$ of the ostracod assemblage. The density is $<1000$ valves per $10 \mathrm{~g}$ of sediment. 
Unit B comprises $63 \%$ silts and clays, $17 \%$ sands, and $20 \%$ gravels. The gravels fraction is dominated by ceramic fragments. There is no color change in relation to unit $\mathrm{A}$. The unit is dated between 370-175 cal BCE and 775-1200 cal CE (1050 \pm 80 BP) (Table 1; Fig. 2).

The study of the ostracods allowed us to divide unit B into two subunits. Subunit B1 shows a high density of ostracods (between 530 and 4800 valves for $10 \mathrm{~g}$ of sediment). The ecology shows that lagoonal (C. torosa) ostracods dominate this assemblage ( $75 \%$ of the valves). The remaining $25 \%$ comprise freshwater (Fabaeformiscandona cf. caudata, Candona neglecta, Iliocypris sp.) and fresh to brackish water species (Heterocypris salina). In subunit B2 the faunal density is lower and never exceeds 800 valves per $10 \mathrm{~g}$ of sediment (mean density $=511$ valves for $10 \mathrm{~g}$ of sediment). Fresh to brackish water species represent $45 \%$ of the faunal assemblage, and C. torosa is still dominant with $55 \%$ of the identified valves.

Unit $\mathrm{C}$ is sandier (27\%), but silts and clays still dominate the total texture $(70 \%)$. The gravels represent $(3 \%)$ of the sediment aggregate. The faunal density is very low with a maximum density of around 75 valves for $10 \mathrm{~g}$ of sediment in the middle of the unit. $C$. torosa is also dominant in this unit, comprising $93 \%$ of the valves. Freshwater species are sporadically present in some samples and represent up to $5 \%$ of the total assemblage.

\subsection{Sediment record from a kiln firing chamber and a sakieh well at Akadémia}

Akadémia is located on the southwestern shore of Lake Maryut, close to the ancient site of Marea-Philoxenite, ca. $8 \mathrm{~km}$ southwest of Kôm de la Carrière (Fig. 1) on the piedmont of the same Gebel Maryut Pleistocene ridge. Archeological remains at Akadémia are composed of an amphora workshop (kilns, activity level and a big waste dump) and a wine press from the 2nd century CE and hydraulic structures from the 5 th to early 7 th century CE. The plan view of one of the amphora kilns shows a semi-buried circular structure $12.65 \mathrm{~m}$ in outside diameter and $7.7 \mathrm{~m}$ in inside diameter. The firing chamber of the amphora kiln was cored in order to probe its volume and infilling (core AKA19; Fig. 3). The base of the firing chamber was found $4 \mathrm{~m}$ below the oven floor at $0.6 \mathrm{~m}$ below msl (mean sea level). The first deposit is a composite, comprising eight layers, 0.1 to $10 \mathrm{~cm}$ thick, of ashen and char sediments intercalated with silty sands and fragments of fired clay bricks. This first deposit translates the kiln activity. It is mainly overlain by fragments of fired clay bricks within a sandy silt matrix, related to the abandonment and the infilling stage of the structure. Four well-defined layers of clayey silts, $5-10 \mathrm{~cm}$ thick and including a few specimens of the freshwater ostracod Ilyocypris sp., were intercalated in the coarse sedimentary infilling.

Core AKA12 retrieved the infilling of a sakieh well found on the western part of Akadémia and is dated to the 5th to early 7th centuries CE (Fig. 3). The sequence is $3.8 \mathrm{~m}$ thick. At the base, unit $\mathrm{A}$ is made of alternating fine to coarse oolitic sand layers, including a few shell fragments and aeolianite gravels corresponding to the upper altered bedrock. The first depositional layer in the well comprises hydromorphic clayey sandy silts (unit B) with a few specimens of the freshwater ostracod Candona sp. and potsherd fragments. Unit C is broadly made up of a conglomerate of gravels and pebbles within a brown silty-sand matrix. This unit $\mathrm{C}, 1.5 \mathrm{~m}$ thick, likely derived from the abandonment and partial destruction of the sakieh's structure. The latter was stabilized during the last deposition of unit $\mathrm{D}$, characterized by homogeneous yellowish brown silty sands. The well's base was found at $0.6 \mathrm{~m}$ below msl, while an estimate for the sakieh's hydraulic wheel diameter and position (Pichot and Empereur, 2013, Annexe IV, p. 88) shows that the water level in the sakieh's well when in use was around $1 \mathrm{~m}$ above msl (Fig. 3).

\section{Sediments from section M83 (Fig. 4)}

\subsection{Unit A: the Maryut marine lagoon}

The upper unit A comprises an alternation of shell-rich and dark mud layers deposited at the centimetric scale. Shellrich layers comprise very abundant shell fragments and well-preserved and abundant gastropods, mollusks and ostracod valves, the latter sometimes still in connection. Species density is high and diversity low, dominated by Hydrobia ventrosa (50\%-95\%), followed by Cerastoderma glaucum, Loripes lacteus, Bittium reticulatum and Abra sp. The ostracod assemblage appears monospecific, represented by the ubiquist, euryhaline and opportunist species Cyprideis torosa (Frenzel and Boomer, 2005). The ${ }^{87} \mathrm{Sr} /{ }^{86} \mathrm{Sr}$ values of Cyprideis torosa valves taken from this unit are around 0.7090 except one sample close to 0.7086 . The upper unit A ends with the deposition of a $4 \mathrm{~cm}$ thick layer almost exclusively composed of shell fragments from the same species as the unit $\mathrm{A}$ assemblage.

\subsection{Units B and C: reworked Lake Mareotis muds?}

Unit B is $0.8 \mathrm{~m}$ thick and comprises homogeneous silty clays (90\%-95\% of the bulk sediment), dark gray to brown, with a lumpy structure. Gypsum dominates the composition of the sand fraction mainly in discoidal lenticular forms. In sectional view, fine white gypsum was observed in the form of nodules and a mycelium-like morphology. Macrofauna and microfauna are scarce in this unit, but nonetheless the gastropods Planorbis planorbis and the ostracod Ilyocypris sp. are present, indicators of lightly brackish conditions, together with lagoonal and marine lagoonal species. These low-brackish conditions are confirmed by the ${ }^{87} \mathrm{Sr} /{ }^{86} \mathrm{Sr}$ signature that decreases significantly to 0.70805 at the base of the unit, although the whole facies is characterized by important fluctuations ranging between 0.70805 and 0.7087 
(a)

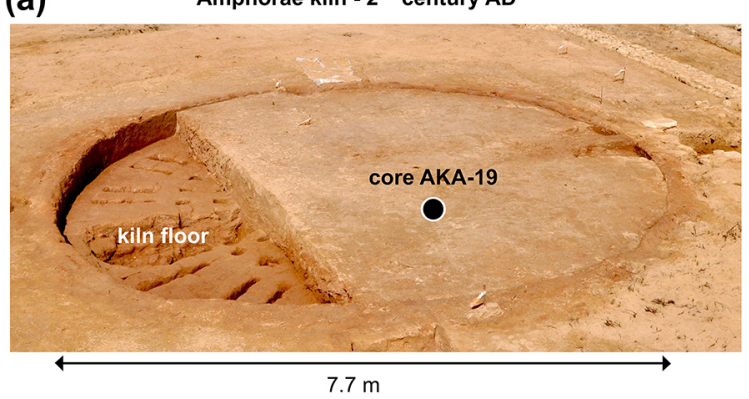

(b)

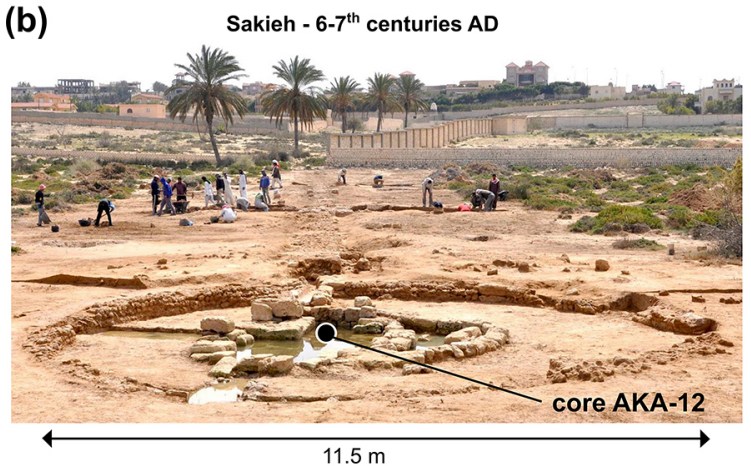

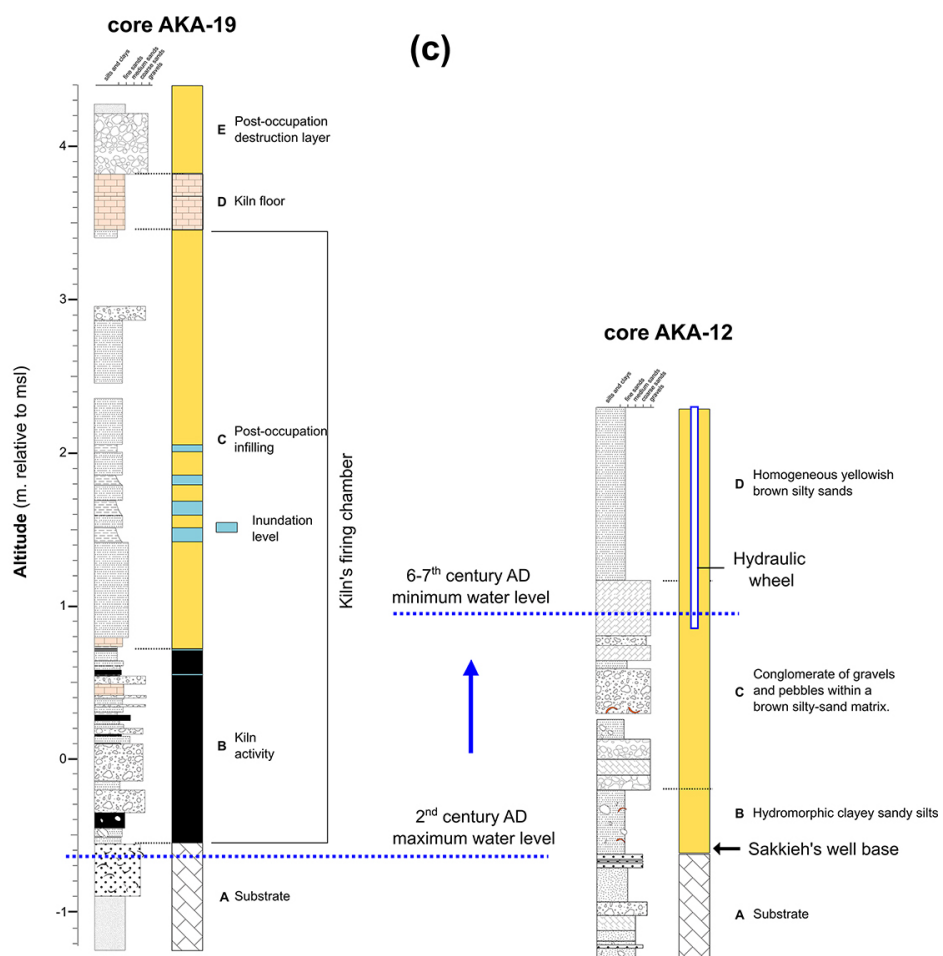

Figure 3. Akadémia archeological site. (a) A 2nd century CE amphora kiln. (b) A 5th to early 7th century CE sakieh (Egyptian water wheel) $500 \mathrm{~m}$ westward from the kiln. Both structures are located at ca. $150 \mathrm{~m}$ from the modern lakeshores in a similar configuration at the foothill of a Pleistocene coastal ridge covered by late Quaternary aeolian sands. (c) Comparison between cores AKA-19 and AKA-12 stratigraphies. The water table must have been below the kiln chamber during its use, then above the lower water wheel, showing a rise between the 2 nd to the 5th century CE.

(Fig. 4). The transition between units A and B is characterized by a decrease in the faunal density and $\mathrm{Sr}$ isotope ratio and a sudden increase in magnetic susceptibility from 0 to $70 \times 10^{-8} \mathrm{~m}^{3} \mathrm{~kg}^{-1}$.

The next unit $\mathrm{C}$ comprises compact dark gray clayey silts with a lumpy structure. There is a rich gypsum layer with a pseudo-mycelium structure. Macrofauna density remains are just a few individuals per $100 \mathrm{~g}$ of dry sediment, although it peaks to $>10$ individuals towards the lower half of the unit, dominated by lightly brackish species (Planorbis planorbis and Bellamya sp.); Cyprideis torosa density increases rapidly from tens to hundreds of individuals from the base of unit $\mathrm{C}$ then decreases to tens of individuals per gram of sediments. The ${ }^{87} \mathrm{Sr} /{ }^{86} \mathrm{Sr}$ ratio in unit $\mathrm{C}$ ranges between 0.7083 and 0.70855 .

Radiocarbon data from units $\mathrm{B}$ and $\mathrm{C}$ show great inconsistency (Fig. 4). Three samples, taken from the base of unit $\mathrm{B}$, display ages ranging from $900 \mathrm{BCE}$ to $950 \mathrm{CE}$. A shell from the middle of unit B was dated to 760-420 BCE, while a burnt bone taken from the same level dates to late Pleistocene times (>45700 BCE; Fig. 4). Lastly, the upper unit C was dated from 540 to 200 BCE. Such a discrepancy, coupled with age inversions, suggests that units $B$ and $C$ consist of reworked muds. Given the macrofauna and ${ }^{87} \mathrm{Sr} /{ }^{86} \mathrm{Sr}$ and ${ }^{14} \mathrm{C}$ data, these muds were mostly reworked from lightly brackish lake bottoms deposited between the first millennium BCE and the first millennium CE.

\subsection{Unit D: Lagoon regression}

The lower and upper interfaces of unit D were sharply defined. The facies shows an increase in fine-sand inputs that reach ca. $50 \%$ of the sediment bulk. Sands are dominated by quartz minerals. A laminated structure is partially preserved with alternations of sand-rich and mud-rich infra-millimetric layers. The faunal assemblage is characterized by the return of lagoonal species sensu stricto and an increase in Cyprideis torosa densities up to several thousand individuals per gram of dry sediment. Three ${ }^{87} \mathrm{Sr} /{ }^{86} \mathrm{Sr}$ values display a narrow range between 0.709 and 0.7091 and signal the return of marine-dominated conditions.

\subsection{Unit E: final lagoon stage}

Unit E provides the last record of section M83. The sand fraction, dominated by quartz minerals, decreases to $25 \%-50 \%$ in the lower half and 10\%-25\% in the upper part. The unit contains a few individuals of lagoonal shells (Hydrobia sp. and Cerastoderma glaucum). The ${ }^{87} \mathrm{Sr} /{ }^{86} \mathrm{Sr}$ ratio comprises 


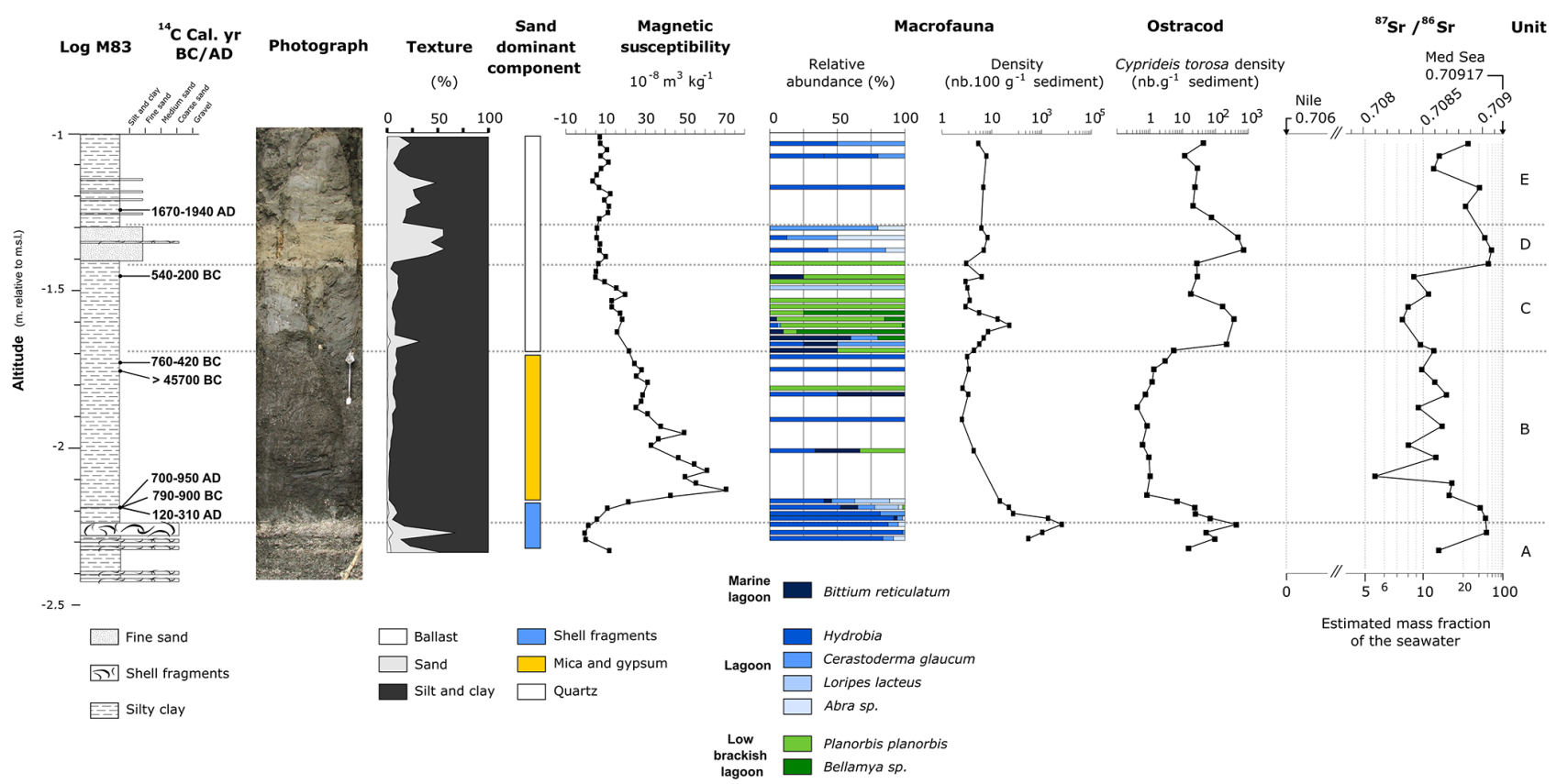

Figure 4. Multi-proxy analysis of section M83 taken from southeastern Lake Maryut (Fig. 1). The mass fraction of seawater was estimated via a two-component mixing equation using modern seawater and Nile river water ${ }^{87} \mathrm{Sr} /{ }^{86} \mathrm{Sr}$ signatures (details in Reinhard et al., 1998 and Flaux et al., 2013)

a wider range between 0.7086 and 0.709 , indicating a fluctuating water budget from fluvial to marine dominated. A charcoal sample was radiocarbon dated to the modern period, in agreement with historical accounts from the 16th to the 18th centuries CE, which describe, from year to year, alternating lacustrine, lagoonal and salt marsh landscapes in the Maryut basin (Flaux et al., 2012).

\section{Lake Mareotis' contrasting sedimentary record}

\subsection{Lake Mareotis desalinization during the first millennium BCE and Roman water-level rise}

Mixed sediments deposited in section M83 have nevertheless recorded, according to fauna and ${ }^{87} \mathrm{Sr} /{ }^{86} \mathrm{Sr}$, dominant Nile inputs to Maryut's water budget for a broad period spanning the first millennium BCE to the first millennium CE. This assessment is confirmed by lagoonal to freshwater ostracods found in core AMR-3 taken in a sheltered context in relation to Maryut's southeastern central basin, i.e., the semi-closed inundated quarry located along the western Maryut margin (Fig. 2). These data show that Lake Mareotis was connected to the Nile. Geoarcheological data at Akadémia and Kôm de la Carrière confirm and refine hydrological conditions in Greco-Roman times.

At Akadémia, the kiln and the sakieh lie $500 \mathrm{~m}$ from each other in a similar geomorphological context at the foothill of a Pleistocene coastal ridge covered by late Quaternary aeolian sands (El-Asmar and Wood, 2000) ca. $150 \mathrm{~m}$ from the modern Lake Maryut shoreline. The base of the kiln's firing chamber lies at a similar depth to the base of the sakieh well, suggesting a rise in the water table between the 2nd (kiln activity) and the 5th to early 7 th (sakieh activity) centuries $\mathrm{CE}$, which is in accordance with clayey silt layers including a few specimens of the freshwater ostracod Ilyocypris sp., translating stagnant water after the inundation of the firing chamber posterior to its use (Fig. 3). In light of estimates for the sakieh's hydraulic wheel diameter and position (Pichot and Empereur, 2013, Annexe IV, p. 88), a minimum rise in the water table of $1.5 \mathrm{~m}$ is inferred (Fig. 3). Because the water table, given the shoreline context of the site and the porosity of loose sediments that compose the substrate of both structures, is probably controlled by the base level of Lake Maryut, it is suggested that Akadémia's remains have recorded a rise in Lake Mareotis' level during Roman times.

The study at Kôm de la Carrière has revealed that the quarry was excavated before or at the beginning of the Hellenistic period at a time when the level of the lake was below mean sea level (msl), given that it is not possible to extract the stones below shallow water (Fig. 2). Following a subsequent rise in water level, the quarry was transformed into a lightly brackish to freshwater basin connected to Lake Mareotis (unit A) and maybe used as a protected harbor. Alternatively, the quarry could have been excavated while disconnected from the lake before the excavation of a canal towards the lake. However, the great porosity of the bedrock, made of poorly consolidated fine to coarse sand layers, and the proximity of the lake go against this hypothesis. Our 
chronological framework shows that the onset of sedimentation is not much earlier than 370-195 cal years BCE (terminus post quem), which is consistent with excavations and archeological surveys undertaken upon the adjacent Kôm, showing an occupation spanning the Greco-Roman period (Pichot, 2017). Moreover, the basin silted during or after the late Roman period and later, as suggested by late Roman sherds discovered in most of the cores drilled into the silted quarry. Ostracod assemblages from this silting stage (units B1 and B2) comprise $25 \%$ freshwater (Fabaeformiscandona cf. caudata, Candona neglecta, Iliocypris sp.) and fresh to brackish water species (Heterocypris salina), demonstrating important freshwater inputs, although Cyprideis torosa dominates the assemblages and attests to important variations in salinity, possibly related to seasonal Nile floods, in particular in subunit B1. Units B2 and C were deposited between 0 and $1.9 \mathrm{~m}$ above msl (Fig. 2), suggesting that Lake Maryut was disconnected from the sea at the time of deposition and mainly supplied by Nile inflow.

Geoarcheological indicators therefore suggest that (1) Lake Mareotis was a lightly brackish lagoon and (2) its level increased by at least ca. $1.5 \mathrm{~m}$ between the $2 \mathrm{nd}$ and the 5 th centuries CE and lay above msl. Late Pleistocene stiff muds lying below Holocene sediments (Chen and Stanley, 1993) represent a relatively impermeable substratum that could have favored the water-level rise and stabilization above msl. It is not clear, however, whether the lake level stabilized above msl or was a seasonal high level linked to the Nile flood. More data are required to better document the dating and nature of this hydrological change, which is crucial for the interpretation of lakeshore archeological sites. For example, the lake-level rise could partially explain the apparent abandonment of Lake Mareotis' southwestern waterfront during the 3rd-4th centuries CE (Pichot, 2017).

\subsection{Origin of reworked sediments in section M83: a tsunamite?}

M83 chronological framework records a mixed sediment layer (units B and C) deposited between two non-reworked laminated facies (units A and D). The lower unit A is composed of shell-rich layers with a marine ${ }^{87} \mathrm{Sr} /{ }^{86} \mathrm{Sr}$ signature (Fig. 4) intercalated with mud layers. This biofacies is widely attested across Maryut sedimentary archives (Warne and Stanley, 1993; Goodfriend and Stanley, 1996; Flaux et al., 2011, 2012, 2013) and formed within a marine lagoon whose deposition ended at the beginning of the first millennium BCE. The upper unit D comprises aeolian sands alternating with muds (unit D), which is consistent with the lake's drying up stage recorded through evaporitic crust dated from the end of the 1st millennium CE (Flaux et al., 2012). Consistently, units $\mathrm{B}$ and $\mathrm{C}$ show ${ }^{14} \mathrm{C}$ datings from the 1 st millennia $\mathrm{BCE}$ and $\mathrm{CE}$, but the ages are completely reworked within these units, and a sample of late Pleistocene age was incorporated into the sediment matrix. This facies presents (i) dating inversions, (ii) incoherent juxtaposition of marine lagoonal, lagoonal and lightly brackish faunistic assemblages (unit B), (iii) heterogeneous Sr isotopic ratios (0.70805 and 0.7087), (iv) abrupt changes in the magnetic susceptibility signature of the sediments at the base of the unit B, and (v) a broken shell layer observed at the interface between units A and B (Fig. 4). These elements may suggest that units $\mathrm{B}$ and $\mathrm{C}$ resulted from the reworking of Lake Mareotis mud bottoms reworked by a high-energy event. At the lake scale, previous chronologies have highlighted an enigmatic sedimentary hiatus. For instance, in core M12, located in the deeper central part of the lake (Fig. 1), the shell-rich facies (identical to M83's unit A) is directly overlain by a gypsum-rich facies (consistent with M83's unit D), meaning that sediments from the first millennium BCE to the first millennium CE are missing (Flaux et al., 2012 and 2013). In section M3, the upper shelly facies dated from the beginning of the first millennium BCE is overlain by lightly brackish muds from the 2nd-3rd centuries CE (Flaux et al., 2012). Radiocarbon dates from section M83 suggest that sediments may have been reworked from the northern deeper part of the basin and were redeposited southeastwards. Goodfriend and Stanley (1996) previously described reworked sediments in core S79 (location in Fig. 1). Faunal assemblages and ${ }^{14} \mathrm{C}$ and $\delta^{13} \mathrm{C}$ analyses of shells from the upper $2 \mathrm{~m}$ of the sequence show a mixed layer composed of younger freshwater (Corbicula sp., 855 uncal BP) and older reworked lagoonal (Cerastoderma sp., 3900 uncal BP) species. The scenario means that the tsunami wave would have overflowed above the coastal ridge ( $5 \mathrm{~m}$ high above $\mathrm{msl}$ in its lower parts) and across the urban topography of Alexandria, then eroded lake-bottom sediments finally redeposited towards the southeast. In section M83, the shell fragment layer capping unit $\mathrm{A}$ and mixed marine to low-brackish species from unit $\mathrm{B}$ could have resulted from tsunami wave trains, while dominant lightly brackish fauna in unit $\mathrm{C}$ would translate as backwash flow from lake margins. M83's hypothetical tsunamite would have been formed some $20 \mathrm{~km}$ from the sea (Fig. 1). Mega-tsunami sediment imprints can be found several kilometers from the coast (Scheffers and Kelletat, 2003), and reworked silt and clays found at site M83 may represent the distal sediment plume.

According to historical sources, eight tsunamis or highenergy marine events struck the coast of Alexandria during antiquity (Goiran, 2012). Previous research has focused on their sedimentological signatures in cores from Alexandria's ancient maritime harbors. Goiran et al. (2005) identified a coarse deposit with older reworked dates, mixed fauna and coarse sediment inputs, including shock impacts on quartz grains (Goiran, 2012). Radiocarbon dates framing the coarse deposit suggest that it has recorded the tsunami wave that hit Alexandria in 811 or 881 CE (Goiran, 2012). Stanley and Bernasconi (2006) observed a possible tsunamite facies with mixed fauna and slump-like sediment strata. Overall, both studies identified, in several coastal sequences of Alexan- 
dria's eastern harbor, a centennial- to millennial-scale sedimentary hiatus, as in some of the Lake Mareotis' sequences. It remains, however, difficult to link ancient processes to missing sediments. In Lake Mareotis, section M83 may have recorded mixed sediment reworked from the lake bottoms. The younger reworked age is chronologically consistent with the high-energy event, providing a terminus post quem to $700-950$ cal CE. In core M12, given that the gypsum-rich layer following the sedimentary hiatus was dated between the 9th and the 12th centuries CE (Flaux et al., 2012), the 811 or $881 \mathrm{CE}$ tsunami wave may have impacted not only Alexandria's coastal waterfront (Goiran, 2012) but also its southern lakeside. In section M3, however, the sedimentary hiatus spans a shorter period, up to the 2nd-3rd centuries $\mathrm{CE}$, meaning that an older tsunami would have eroded these lake bottoms. Three tsunamic layers deposited during the last 2000 years were found within coastal lagoons protected by 2-20 $\mathrm{m}$ high dunes on the northwestern coast of Egypt (Salama et al., 2018).

Alternatively, recurrent gypsum in pseudo-mycelium form observed in units B and C, as well as their lumpy sediment structure and dark color likely related to higher organic input, suggests the development of pedogenic features at site M83. Soil development would necessarily imply that Lake Mareotis retreated from this area and would likely derive from the lake-level lowstand previously recorded after evaporitic deposits in sequences M3 and M12 between the 9th to the 12th centuries CE (Flaux et al., 2012). Soil biological activity or agricultural plowing could also explain reworking dating along units B and C. Although this alternative hypothesis does not explain the enigmatic sedimentary hiatus recorded from the deeper part of the lake, it shows that the tsunami hypothesis requires deeper investigation. Synolakis and Fryer (2001) and Marriner et al. (2017) caution that every coastal enigma does not necessarily have a tsunami explanation.

\section{Conclusion}

Lake Mareotis was densely occupied during Greco-Roman times. The present contribution aims to better constrain hydrological conditions of the lake during this period. Faunal remains, the Sr isotopic signature of ostracods and geoarcheological indicators of lake levels show both a rise in Nile inputs to the basin during the first millennia BCE and CE and a lake-level rise of ca. $1.5 \mathrm{~m}$ during the Roman period. Such changes highlight a complex co-evolution of Alexandria's lakeside occupation history and Nile flow changes, the latter being divided into fluctuating distributaries at the delta scale that were furthermore diverted by irrigation and drainage networks (e.g., Blouin, 2006). From a forward-looking viewpoint, the Alexandria canal (see location in Fig. 1) may have played a crucial role in the evolution of Lake Mareotis' water budget: (1) it has partially diverted the Canopic Nile flow towards the delta's western margin, and (2) it has disconnected the lake from the Aboukir lagoon and thus from the sea, favoring Lake Mareotis' desalinization and allowing its level to rise above msl, as observed at Akadémia and Kôm de la Carrière archeological sites. In any case, desalinization of the northwestern Nile Delta margin could have been key in the development of human occupation in this area during the first millennium BCE. At this time, Lake Mareotis became the natural conveyor for drainage and irrigation water. Since the Hellenistic period at least, there was increasing management of the water system around Lake Mareotis, a process which was accelerated during the Roman period (Pichot, 2017) and may have played a significant role in driving lake-level changes.

Lake Mareotis' configuration was transformed by the 9th century CE from a high-level, hypohaline coastal lake to a sebkha. While we previously related this environmental change to the progressive silting up of the Canopic branch and northwestern delta irrigation system, our new results instead highlight an environmental change related to the impact of possible high-energy event(s). A reconstruction of Lake Mareotis history requires new approaches and perspectives (Crépy and Boussac, 2021).

Data availability. All data generated during this study are included in this article or are available from the corresponding author upon request.

Author contributions. CF, MG, VP, NM, MeA, AG, PD, CC and $\mathrm{CM}$ conceived the study and wrote the paper. CF, VP, NM, CM and MeA performed fieldwork and provided chronostratigraphies. MG performed ostracod analyses. CF, AB, PP and CC performed $\mathrm{Sr}$ isotopes analyses.

Competing interests. The authors declare that they have no conflict of interest.

Special issue statement. This article is part of the special issue "Geoarchaeology of the Nile Delta". It is not associated with a conference.

Acknowledgements. We thank Hélène Mariot for taking care of CEREGE's clean lab. Matthieu Giaime acknowledges the support of the Institute of Advanced Studies and the Department of Geography at Durham University. We thank two anonymous referees for constructive comments on an earlier version of the manuscript. We thank Martin Seeliger for kindly translating the abstract into German. 
Financial support. This research has been supported by the ANR (France) (grant no. ANR-12-SENV-0008-03), the Investissement d'Avenir (France) (grant no. EQUIPEX ASTER-CEREGE), and the Durham Junior Research Fellowship (grant no. 609412).

Review statement. This paper was edited by Julia Meister and reviewed by two anonymous referees.

\section{References}

Athersuch, J., Horne, D. J., and Whittaker, J. E.: Marine and Brackish Water Ostracods (Superfamilies Cypridacea et Cytheracea): Keys et Notes for the Identification of the Species, Brill Archive, New Work, USA, 1989.

Bernasconi, M. P. and Stanley, D. J.: Molluscan biofacies and their environmental implications, Nile delta lagoons, Egypt, J. Coast. Res., 10, 440-465, 1994.

Blouin, K.: Homme et milieu dans le nome mendésien à l'époque romaine (1er au 6e s.), PhD thesis, University of Nice Sophia Antipolis, France and University of Laval, Québec, Canada, 558 pp., 2006 (in French).

Blue, L. and Khalil, E. (Eds.): Lake Mareotis: Reconstructing the Past, Proceedings of the International Conference on the Archaeology of the Mareotic Region, Bar International Series 2113, Oxford, England, 2010.

Butzer, K. W.: Early Hydraulic Civilization in Egypt, University of Chicago Press, Chicago, USA, 1976.

Chen, Z. and Stanley, D. J.: Alluvial stiff muds (late Pleistocene) underlying the lower Nile delta plain, Egypt: petrology, stratigraphy and origin, J. Coast. Res., 9, 539-576, 1993.

Crépy, M. and Boussac, M.-F.: Western Mareotis lake(s) during the Late Holocene (4th century BCE-8th century $\mathrm{CE}$ ): diachronic evolution in the western margin of the Nile Delta and evidence for the digging of a canal complex during the early Roman period, E\&G Quaternary Sci. J., 70, 39-52, https://doi.org/10.5194/egqsj-70-39-2021, 2021.

De Cosson, A.: Mareotis, Being a Short Account of the History of Ancient Monuments of the North-western Desert of Egypt and of Lake Mareotis, Country Life Ltd., London, USA, 1935.

El-Asmar, H. M. and Wood, P.: Quaternary shoreline development: the northwestern coast of Egypt, Quaternary Sci. Rev., 19, 1137 1149, https://doi.org/10.1016/S0277-3791(99)00097-9, 2000.

El-Fakharani, F. A.: The Kibotos of Alexandria, Studi Miscellanei, 28, 21-28, 1991.

Empereur, J.-Y.: Alexandrie redécouverte. Fayard, Paris, 254 pp., 1998.

Flaux, C.: Holocene Coastal Palaeo-environment of Maryut Lake in the Northwestern Nile delta, Egypt, PhD thesis, Aix-Marseille University, Marseille, France, 413 pp., 2012.

Flaux, C., Morhange, C., Marriner, N., and Rouchy, J.-M.: Bilan hydrologique et biosédimentaire de la lagune du Maryût (delta du Nil, Egypte) entre 8000 et 3200 ans cal. B.P., Géomorphologie, 3, 261-278, https://doi.org/10.4000/geomorphologie.9474, 2011.

Flaux, C., El-Assal, M., Marriner, N., Morhange, C., Rouchy, J.-M., Soulié-Märsche, I., and Torab, M.: Environmental changes in the Maryut lagoon (northwestern Nile delta) dur- ing the last 2000 years, J. Archaeol. Sci., 39, 3493-3504, https://doi.org/10.1016/j.jas.2012.06.010, 2012.

Flaux, C., Claude, C., Marriner, N., and Morhange, C.: A 7500 years strontium isotope record from the northwestern Nile delta (Maryut lagoon, Egypt), Quaternary Sci. Rev., 78, 22-33, https://doi.org/10.1016/j.quascirev.2013.06.018, 2013.

Flaux, C., El-Assal, M., Shaalan, C., Marriner, N., Morhange, C., Torab, M., Goiran, J.-P., and Empereur, J.-Y.: Geoarchaeology of Portus Mareoticus: Ancient Alexandria's lake harbour (Nile Delta, Egypt), J. Archaeolog. Sci. 13, 669-681, https://doi.org/10.1016/j.jasrep.2017.05.012, 2017.

Frenzel, P. and Boomer, I.: The use of ostracods from marginal marine, brackish waters as bioindicators of modern and Quaternary environmental changes, Palaeogeogr. Palaeocl., 225, 68-92, 2005.

Goiran, J.-P.: Caractérisation d'un dépôt de tsunami dans le port antique d'Alexandrie par l'étude exoscopique des quartz: apports et limites de la méthode, in: Archéosismicité \& Tsunamis en Méditerranée, Approches croisées, edited by: Rébé-Marichal, I., Laurenti, A., Boehm, I., and Goiran, J.-P., Editions APS, Perpignan, France, 157-190, 2012 (in French).

Goiran, J.-P., Marriner, N., Morhange, C., Abd El-Maguid, M. Espic, K., Bourcier, M., and Carbonel, P.: Évolution géomorphologique de la façade maritime d'Alexandrie (Egypte) au cours des six derniers millénaires, Méditerranée, 104, 61-65, https://doi.org/10.4000/mediterranee.2132, 2005 (in French).

Goiran, J.-P., Vittori, C., Noirot, B., and Torab, M.: Relative Sea Level Variations at Alexandria (Nile Delta, Egypt) over the Last Millennia: Archaeological Implications for the Ancient Harbour, Verlag der Österreichischen Akademie der Wissenschaften, Wien, 2018.

Goodfriend, G. A. and Stanley, J.-D.: Reworking and discontinuities in Holocene sedimentation in the Nile delta: documentation from amino acid racemization and stables isotopes in mollusks shells, Mar. Geol., 129, 271-283, https://doi.org/10.1016/00253227(96)83348-2, 1996.

Marriner, N., Kaniewski, D., Morhange, C., Flaux, C., Giaime, M., Vacchi, M., and Goff, J.: Tsunamis in the geological record: Making waves with a cautionary tale from the Mediterranean, Sci. Adv., 3, 10, https://doi.org/10.1126/sciadv.1700485, 2017.

Pichot, V.: Aux portes d'Alexandrie. Le développement de la Maréotide hellénistique et romaine, $\mathrm{PhD}$ thesis, Lyon 2 Lumière University, Lyon, France, 1391 pp., 2017 (in French).

Pichot, V. and Empereur, J.-Y.: Rapport de la campagne de fouille juin-août 2013 sur le site d'Akadémia (Égypte), Rapport pour le Ministère de l'Europe et des affaires étrangères, CEAlex, Alexandria, Egypt, 102 pp., 2013 (in French).

Pichot, V. and Flaux, C.: Les fours à amphores du Haut-Empire du site d'Akadémia (Maréotide): campagne de fouille et carottages 2014, Bulletin de liaison de la Céramique Égyptienne (BCE), 25, 259-276, 2015 (in French).

Pin, C., Briot, D., Bassin, C., and Poitrasson, F.: Concomitant separation of strontium and samarium-neodymium for isotopic analysis in silicate samples, based on specific extraction chromatography, Anal. Chim. Acta, 298, 209-217, 1994.

Redon, B., Vanpeene, M., and Pesenti, M.: La vigne a été inventée dans la ville égyptienne de Plinthine, A propos de la découverte d'un fouloir saïte à Kôm el-Nogous (Maréotide), Bulletin 
de l'Institut français d'archéologie orientale (BIFAO), 116, 303323, https://doi.org/10.4000/bifao.440, 2017 (in French).

Reimer, P., Austin, W., Bard, E., Bayliss, A., Blackwell, P., Bronk Ramsey, C., Butzin, M., Cheng, H., Edwards, R. L., Friedrich, M., Grootes, P. M., Guilderson, T. P., Hajdas, I., Heaton, T. J., Hogg, A. G., Hughen, K. A., Kromer, B., Manning, S. W., Muscheler, R., Palmer, J. G., Pearson, C., van der Plicht, J., Reimer, R. W., Richards, D. A., Scott, E. M., Southon, J. R., Turney, C. S. M., Wacker, L., Adolphi, F., Büntgen, U., Capano, M., Fahrni, S. M., Fogtmann-Schulz, A., Friedrich, R., Köhler, P., Kudsk, S., Miyake, F., Olsen, J., Reinig, F., Sakamoto, M., Sookdeo, A., and Talamo, S.: The IntCal20 Northern Hemisphere Radiocarbon Age Calibration Curve (0-55 cal kBP), Radiocarbon, 62, 725-757, https://doi.org/10.1017/RDC.2020.41, 2020.

Reinhardt, E. G., Stanley, J.-D., and Patterson, R. T.: Strontium isotopic paleontological method as a high-resolution paleosalinity tool for lagoonal environments, Geology, 26, 1003-1006, 1998.

Salama, A., Meghraoui, M., El Gabry, M., Maouche, S., Hussein, M. H., and Korrat, I.: Paleotsunami deposits along the coast of Egypt correlate with historical earthquake records of eastern Mediterranean, Nat. Hazards Earth Syst. Sci., 18, 2203-2219, https://doi.org/10.5194/nhess-18-2203-2018, 2018.

Scheffers, A. and Kelletat, D.: Sedimentologic and geomorphologic tsunami imprints worldwide - a review, Earth-Sci. Rev., 63, 8392, 2003.
Stanley, J.-D.: Egypt's Nile Delta in Late 4000 Years BP: Altered Flood Levels and Sedimentation, with Archaeological Implications, J. Coast. Res., 35, 1036-1050, https://doi.org/10.2112/JCOASTRES-D-19-00027.1, 2019.

Stanley, J.-D. and Bernasconi, M. P.: Holocene Depositional Patterns and Evolution in Alexandria's Eastern Harbor, Egypt, J. Coast. Res., 22, 283-297, https://doi.org/10.2112/04-0348.1, 2006.

Sun, Q., Liu, Y., Salem, A., Marks, L., Welc, F., Ma, F., Zhang, W., Chen, J., Jiang, J., and Chen, Z.: Climate-induced discharge variations of the Nile during the Holocene: Evidence from the sediment provenance of Faiyum Basin, north Egypt, Global Planet. Change, 172, 200-210, 2019.

Synolakis, C. and Fryer, G. J. : Review of: Tsunami: The underrated hazard, EOS, 82, 588, https://doi.org/10.1029/01EO00342, 2001.

Warne, A. G. and Stanley, D. J.: Late Quaternary evolution of the northwest Nile delta and adjacent coast in the Alexandria region, Egypt, J. Coast. Res., 9, 26-64, 1993.

Wilson, P.: Waterways, settlements and shifting power in the northwestern Nile Delta, Water Hist., 4, 95-117, https://doi.org/10.1007/s12685-012-0053-z, 2012.

Yoyotte, J., Charvet, P., and Gompertz, S.: Strabon, le voyage en Egypte, un regard romain, Nil Edition, Paris, France, 1997. 